\title{
The pitfalls of extrapolating modern depth ranges to fossil assemblages: new insights from Middle Jurassic brittle stars (Echinodermata: Ophiuroidea) from Switzerland
}

\author{
Ben Thuy $\cdot$ Christian A. Meyer
}

Received: 4 July 2012/Accepted: 22 October 2012/Published online: 7 December 2012

(C) Akademie der Naturwissenschaften Schweiz (SCNAT) 2012

\begin{abstract}
Depth reconstruction based on the extrapolation to fossil assemblages of present-day depth ranges of closely related groups is one of the most widely used approaches in palaeobathymetry. Here, we assess the ophiuroid fauna of the Bajocian to Bathonian (Middle Jurassic) Hauptrogenstein Formation and coeval formations in Switzerland with respect to the depth ranges of extant members of the groups identified. In addition to previously known taxa, we describe three new species, one assignable to the extant genus Ophiotholia within the family Ophiomycetidae (resurrected herein), and two belonging to new genera within the family Ophiacanthidae. The Hauptrogenstein ophiuroid fauna is shown to display a striking similarity to modern bathyal brittle star assemblages. In combination with taphonomic evidence of the autochthonous nature of the ophiuroid occurrences, the direct extrapolation of present-day depth ranges, as performed in various previous studies, would imply the Hauptrogenstein Formation to have been deposited in a bathyal setting. This, however, is in stark contrast with the generally accepted, sedimentology-based concept of this unit as a very shallow, highenergy carbonate platform deposit. Evidently, direct extrapolation of modern depth distribution patterns fails to provide a reliable palaeobathymetrical assessment here. In this respect, the case of the Hauptrogenstein ophiuroid fauna serves as a remarkable example to stress the pitfalls of
\end{abstract}

B. Thuy $(\bowtie)$

Department of Geobiology, Geoscience Centre,

University of Göttingen, Goldschmidtstraße 3,

37077 Göttingen, Germany

e-mail: nebyuht@yahoo.com

C. A. Meyer

Naturhistorisches Museum Basel, Augustinergasse 2,

4001 Basel, Switzerland assemblage-based palaeodepth estimates: (1) depth distribution patterns might not be controlled by water depth, or not even by a factor directly related to depth, (2) habitat preferences of a group might have changed through time without being reflected by morphological modifications and (3) shifts in depth ranges might occur due to the rise or extinction of groups interacting with the organism in question. Thus, extrapolation of present-day depth ranges to ancient communities can only produce reliable palaeodepth estimates if there is a mechanistic explanation why organisms are confined to a particular depth.

Keywords Ophiomycetidae - Ophiacanthidae . Ophiuroids $\cdot$ Palaeobathymetry $\cdot$ Taxonomy

\section{Introduction}

Reconstructing environmental conditions of ancient depositional settings is the prime goal of palaeoecology and facies analysis. Depth of deposition is definitely not only the most important but also the most challenging among parameters of interest in marine palaeoenvironmental interpretations. Modern sequence stratigraphy and studies of macroevolutionary patterns commonly rely on robust palaeodepth reconstructions which go well beyond the simplistic notion of "shallow" or "deep". While water depth can be directly measured in modern marine environments, ancient bathymetries have to be inferred from evidence preserved in the sedimentary record (e.g. Flügel 2004). Various sources of evidence have been explored with respect to their potential as palaeodepth indicators, including sedimentary structures and textures (e.g. Allen 1967; Bathurst 1967), authigenic minerals (e.g. Porrenga 1967), stable isotopes (e.g. Oberhänsli 1984), ichnofacies 
(e.g. Seilacher 1967), micro-endolithic ichnofossils (e.g. Hofmann 1996) and fossil communities including microfaunas (e.g. Funnell 1967; Bourbon et al. 1980; Benson 1984; Charbonnier et al. 2007). Especially the last-named have received particular attention in recent years as they provide for easily accessible and potentially powerful palaeodepth indicators in cases where sample size is very small (e.g. sediment cores) or where deposits are devoid of informative sedimentary structures.

Probably the most important factor boosting the interest in assemblage-based palaeodepth estimates, however, is the tremendous progress made in recent decades in the understanding and documentation of present-day marine benthic communities and their depth distribution, which have provided an array of tempting modern analogues for ancient communities. The dramatic changes in faunal composition along the depth gradient, discovered in the early days of deep-sea research, have been intensively investigated during the past decades (e.g. Menzies et al. 1973; Gage and Tyler 1991). As a result, it is now well known that most modern groups, assemblages and abundance patterns among taxa are restricted to a particular depth range (Phleger 1960, 1964; Boltovskoy 1965; Benson 1984). In some groups, faunal composition patterns change so rapidly along the depth gradient that they have been suggested as basis for bathymetrical zonation models (Menzies et al. 1973). In the light of these, it is not surprising that countless attempts have been made to extrapolate the present-day depth distribution data directly to fossil relatives. Considering, however, how little is known about the factors which control the bathymetrical distribution of organisms, a direct application of these patterns to fossil assemblages is highly precarious.

Here, we assess the ophiuroid fauna of the Middle Jurassic Hauptrogenstein Formation of Switzerland, one of the most extensively studied formations of this age, from a palaeobathymetrical point of view. Our aim is to test the widely applied actualistic approach estimating palaeodepths on the basis of direct comparison with present-day bathymetrical distribution patterns of close modern relatives. The assessment includes the description of previously unknown, palaeoecologically highly relevant components of the Hauptrogenstein ophiuroid fauna. We oppose the results of our actualistic assemblage-based depth interpretation to the robust palaeobathymetrical models available for the Hauptrogenstein based on sedimentological evidence. Finally, we discuss the implications for assemblage-based palaeodepth estimates in the absence of a comprehensive explanation of the factors controlling the present-day bathymetrical distribution patterns of the relevant groups.

This study is based on material housed at the Naturhistorisches Museum Basel (NMB). Many of the specimens have been described and/or figured in previous accounts on the
Hauptrogenstein fauna (Hess 1972; Hess and Holenweg 1985). Documentation of the specimens was carried out using digital microphotography (Keyence VHX-500F) and, when applicable, a scanning electron microscopy (LEO 1530 Gemini). Terminology follows Thuy and Stöhr (2011) and Stöhr et al. (2012). Higher taxonomic classification is adopted from Smith et al. (1995) and Thuy et al. (2012).

\section{Geological context}

The Burgundy carbonate platform with its Bahama-type sediment was a vast area (Fig. 1) with a general highenergy water regime under oligotrophic conditions. All ophiuroid-bearing outcrops, in particular Schinznach, Auenstein (both Canton Aargau) and Schönthal (Canton Basel-Country), display laterally discontinuous, thickly bedded grainstones, a feature typical of the upper part of the Hauptrogenstein Formation. The beds that contain the ophiuroid assemblages consist of medium- to fine-grained oolitic limestone (grainstone) with small-scale cross-bedding. All brittle stars are preserved complete, without any major signs of decay. We interpret the sequences as part of a small calcarenitic, subaquatic dune.

The preservation corresponds to the taphonomic grade 1 Echinoderms of Brett et al. (1997), considered to be extremely rare in the fossil record. Furthermore, the locality of Schinznach can be classified genetically as an obrution deposit and belongs to the widely recognised "Hauptrogenstein type" (Meyer 1988; Brett and Seilacher 1991; Brett et al. 1997).

The presence of widespread blanket-like deposits of echinoderm skeletal grain and packstones with cross-bedding assigns the present Lagerstätte to Taphofacies I A of Brett et al. (1997); carbonate dominated skeletal shoals. According to those authors, this taphofacies is usually found during High Stand Transgressive System Tracts.

The sequence-stratigraphic interpretation of Gonzalez (1996) of the "untere oolithische Serien", the "Obere Oolithische Serien", the coeval Klignau Formation as well as the Varians beds as deposits of a High Stand Transgressive System Tract is in accordance with the interpretation of Brett et al. (1997) that the observed taphofacies is generally found during such system tracts.

\section{Results and discussion}

The Hauptrogenstein ophiuroid community: composition and comparison with modern equivalents

Systematic assessment of ophiuroids from the Hauptrogenstein Formation started as early as the latest nineteenth 
century with the description of Ophiomusium ferrugineum by Boehm (1899). This small, thick-plated species was figured and described several times after its original description (Hess 1975; Hess and Holenweg 1985), but no comprehensive reappraisal of its systematic position has been carried out yet. The presence of tentacle pores up to median arm portions, developed as between-plate openings, precludes assignment to the extant genus Ophiomusium, in spite of an otherwise marked superficial similarity. Kutscher and Jagt (2000) introduced the genus Mesophiomusium to accommodate extinct Ophiomusium-like lateral arm plates with between-plate tentacle openings developed well beyond the basalmost arm segments. However, the type species, M. moenense, is based on dissociated lateral arm plates which bear a close similarity to those of extant Ophiomastus (B. Thuy, personal observation). At present, all available evidence suggests that Ophiomusium ferrugineum most probably belongs to an undescribed genus which shares greatest affinities with the extant ophiolepidids Ophiomusium and Ophiosphalma and the ophiurids Ophiomastus and Ophiomisidium.

The monograph by Hess (1972) added two more species to the Hauptrogenstein ophiuroid fauna, namely Dermocoma wrighti Hess 1964 and Ophiopetra bathonica Hess 1964. The former is herein considered to be an ophiacanthid, as discussed in detail below. Ophiopetra bathonica is close to the extant ophiolepidid Ophiozonella (previously unpublished observation). In their review of the faunal components accompanying the dense crinoid meadows of the Swiss Middle Jurassic, Hess and Holenweg (1985) illustrated and briefly described Sinosura wolburgi Hess, 1960 and Ophiacantha? constricta Hess, 1966. While the latter is transferred to a new genus and new species in the present study, Sinosura wolburgi most probably belongs to the extant ophiurid subfamily Ophioleucinae (Smith et al. 1995; Thuy et al. 2011). The recently described Hauptrogenstein ophiuroid Geocoma schoentalensis Hess \& Meyer, 2008, originally assigned to the

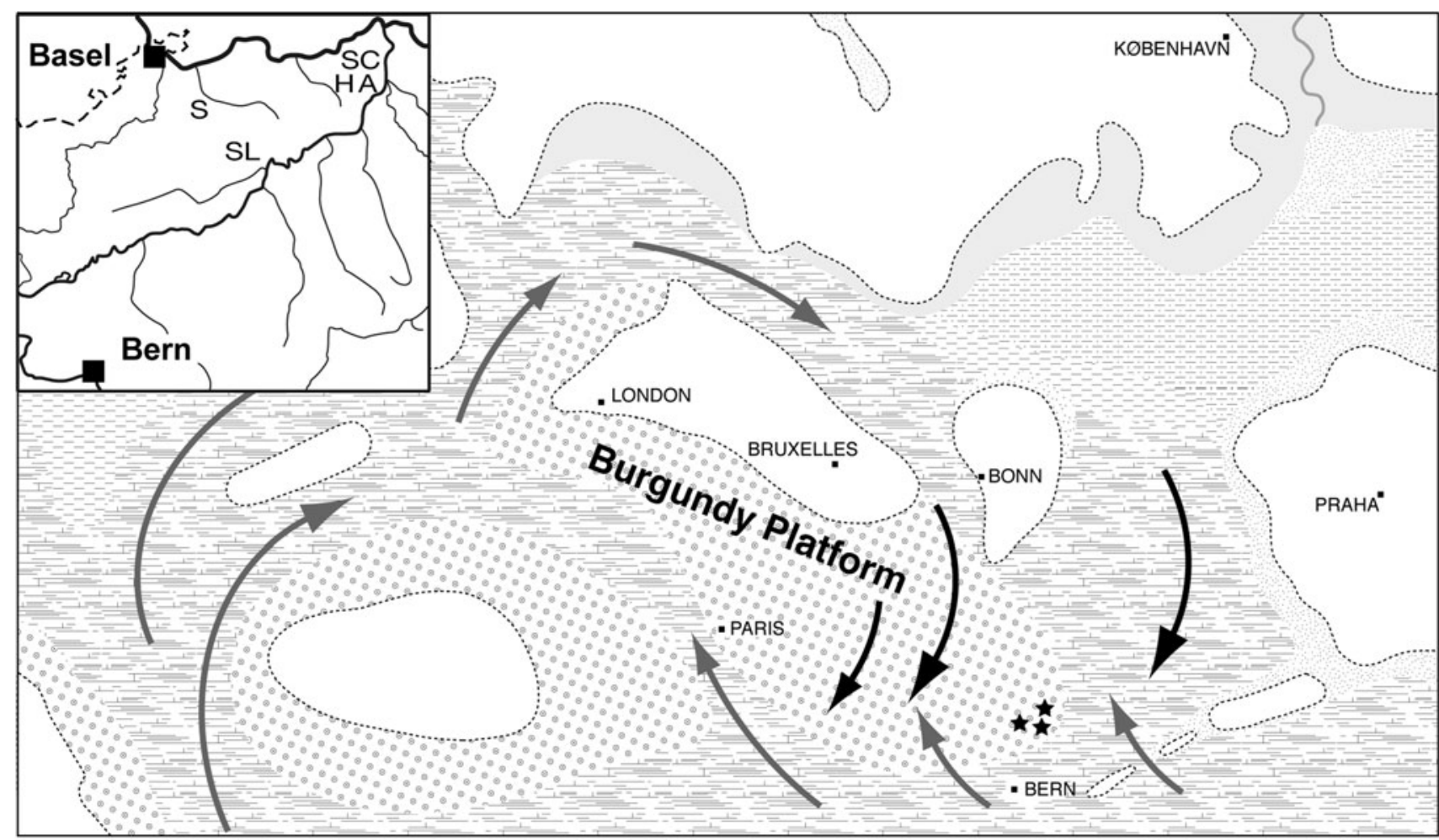

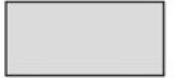

coastal plain

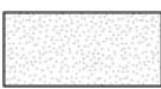

shallow-marine sands

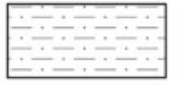

shallow-marine

sandy muds

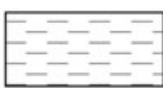

shallow-marine

muds

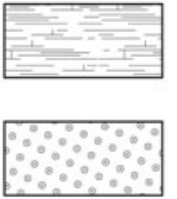

shallow-marine calcareous muds

shallow-marine carbonates, mainly oolites
Fig. 1 Palaeogeographical map of the Bahama-type carbonate platform during the Middle Jurassic, with ophiuroid occurrences in northwest Switzerland (stars) and indication of ebb (black arrows) and tide (grey arrows) currents (arrows). Redrawn from Wetzel et al.
(2013). Inset map shows the localities mentioned in the text: $\mathrm{A}=$ Auenstein, $\mathrm{H}=$ Hottwiler Horn, $\mathrm{S}=$ Sichtern, SC $=$ Schinznach, SL $=$ Schönthal 


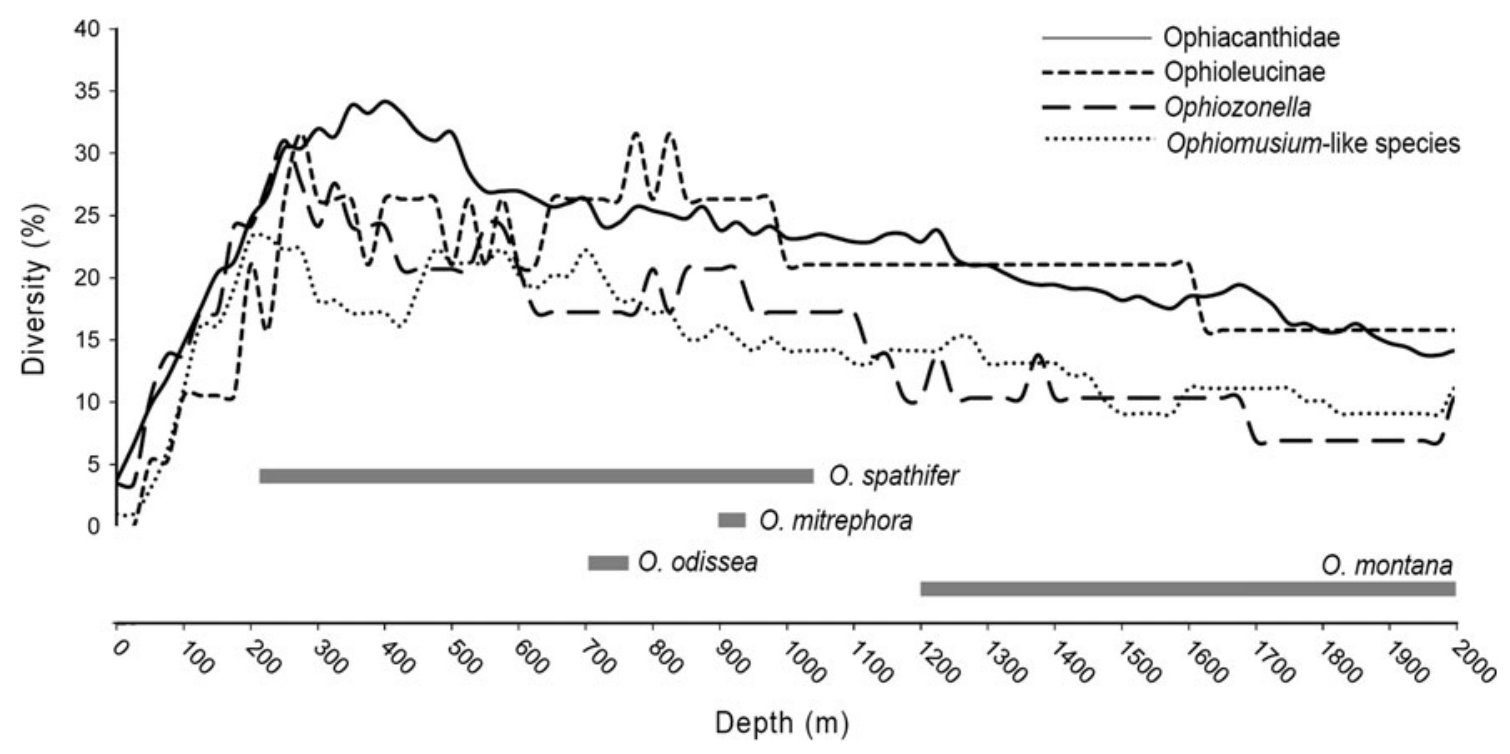

Fig. 2 Diversities of Recent Ophiacanthidae, Ophioleucinae, Ophiozonella and Ophiomusium-like forms (see text for details), indicated as a percentage of the total diversity per group, along the depth gradient, together with depth ranges of Recent species of Ophiotholia

extinct family Aplocomidae, is most probably also best placed in the Ophioleucinae (B. Thuy, pers. obs.).

In addition to these previously recorded ophiuroid species, the present study describes another new ophiacanthid and a new species of the extant genus Ophiotholia. The Hauptrogenstein ophiuroid fauna thus currently comprises three ophiacanthids, a species of the extant ophiomycetid (see below for details) genus Ophiotholia, two probable ophioleucines, one Ophiozonella-like ophiolepidid and one species with strong affinities to the ophiolepidids Ophiomusium and Ophiosphalma and the ophiurids Ophiomastus and Ophiomisidium. When the present-day diversity of these groups is plotted against water depth (Fig. 2), a conspicuous pattern emerges. Diversities are very low in the first $100 \mathrm{~m}$ of the water column, strongly increase between 150 and $200 \mathrm{~m}$, reach their maximum between 200 and $1,000 \mathrm{~m}$ and slowly decrease towards greater depths. This analysis corroborates previous observations that the above-mentioned groups are predominantly, if not exclusively, deep-sea groups (Tyler 1980; Stöhr 2011). The case of extant Ophiotholia is particularly conclusive: no species of this genus occurs in depths shallower than $200 \mathrm{~m}$ (Koehler 1904; Irimura 1982). Ophiuroid assemblages comparable, in terms of composition, to the Hauptrogenstein fauna have been documented, for example, from upper to lower bathyal depths $(200-2,000 \mathrm{~m})$ in the Philippine area (Koehler 1922; Guille 1981) and in the North Pacific (Clark 1911).

A rigorous quantitative assessment of the Hauptrogenstein brittle star fauna is precluded by the patchiness of the ophiuroid occurrences. Nevertheless, the ophiacanthids and (abbreviated 'O.'; grey bars at the bottom of the graph). Depth ranges compiled from Litvinova (1992) for Ophiotholia and from respective original species descriptions [see Stöhr and O’Hara (2007) for a complete list] for other taxa

Ophiomusium ferrugineum account for the majority of independent (i.e. scattered rather than preserved as a single group) occurrences, although they might not necessarily be the most abundant in terms of absolute specimen counts. In fact, of Geocoma schoentalensis a total of 34 specimens are known (Hess and Meyer 2008) which is thus probably represented by the highest number of individuals, but these all belong to a single mass occurrence. In contrast, Ophiotholia aurora and Ophiopetra bathonica both are very rare. An ophiuroid fauna dominated by ophiacanthids and by an Ophiomusium-like ophiolepidid or ophiurid matches the majority of present-day bathyal ophiuroid assemblages (e.g. Lyman 1882, 1883; Koehler 1922; Clark 1911; Tyler 1980).

Actualistic assemblage-based palaeobathymetry vs. sedimentological evidence

The comparison between the Hauptrogenstein ophiuroid fauna and modern-day equivalents clearly shows that similarities are greatest to modern bathyal ophiuroid communities. Supporting evidence comes from the presentday bathymetrical distribution of isocrinids, which constitute the major faunal element of the ophiuroid-producing beds within the Hauptrogenstein Formation. In fact, modern isocrinids predominantly occur in upper to middle bathyal depths (200-1,000 m) (Hess 2011). Given these striking similarities to present-day equivalents, it is tempting to assume that the Hauptrogenstein ophiuroid fauna is, in fact, a bathyal assemblage. Since preservation of articulated ophiuroid skeletons requires rapid and 
effective burial (Ausich 2001), the Hauptrogenstein ophiuroids, most of which retain even the finest structures in place, suffered very little pre-burial transportation, if any at all. Thus, the Hauptrogenstein Formation must have been deposited in bathyal depths.

A deep-sea setting for the Hauptrogenstein Formation is, however, in stark contrast with clear-cut sedimentological evidence in the form of obliquely stratified oolithic to bioclastic grainstones interpreted as tide-induced sand waves in the immediate horizontal and vertical vicinity of the deposits which yield echinoderms (Gonzalez 1996; Gonzalez and Wetzel 1996). Indeed, the Hauptrogenstein Formation is part of the broad oolithic belt on the eastern and central parts of the Middle Jurassic Burgundy platform, widely interpreted as high-energy, shallow-water, Bahamatype carbonate platform (e.g. Mégnien 1980). Taphonomical aspects as well as the geometry of the facies belts and patterns of facies succession within the Hauptrogenstein Formation suggest that the echinoderm beds were deposited in proximal offshoal settings under the influence of storms or strong tidal currents (Meyer 1987, 1990; Gonzalez 1996; Hess et al. 1999).

Dermocoma wrighti, Ophiomusium ferrugineum, Alternacantha occulta gen. et sp. nov. and Sinosura wolburgi occur already at the base of the Hauptrogenstein Formation within dense accumulations of the isocrinid crinoid Chariocrinus andreae (Desor); this part is of Niortense Zone (Bajocian) age and water depth was estimated to have been between 5 and 10 m (Meyer 1987; Gonzalez 1993). Similarly, in the upper part of the Hautprogenstein Formation (outcrops at Auenstein, Schinznach and Schönthal), of Parkinsoni Zone (Bajocian) age and yielding Ophiotholia aurora sp. nov., Hanshessia trochitophila gen. et sp. nov., Ophiopetra bathonica and Alternacantha occulta gen. et sp. nov., palaeowater depth estimates are around 5-10 m (Meyer 1987; Gonzalez 1993).

In addition, Alternacantha occulta gen. et sp. nov. co-occurs with dense accumulations of the comatulid crinoid Paracomatula helvetica Hess and the isocrinid Isocrinus nicoleti (Desor) in the Klingnau Formation at the Hottwiler Horn locality (Canton Aargau), a unit that comprises more marly intercalations and is thought to have been deposited in slightly deeper water $(15-20 \mathrm{~m})$.

This depth range is at least one order of magnitude shallower than the palaeobathymetrical estimate based on the above-performed strictly actualistic interpretation of the Hauptrogenstein ophiuroid assemblage. The competing depth ranges are separated by the continental shelf break (at $130 \mathrm{~m}$ water depth on average), which classically sets the division between the shallow shelf and the deep sea (e.g. Davis 1977) and which marks one of the most important ecological boundaries in the marine realm (e.g. Menzies et al. 1973). It is thus of prime interest to come up with an explanation for the discrepancy between the assemblage-based depth estimate and the general geological evidence.

The reliability of assemblage-based palaeodepth estimates

It is clear from the comparison made above that the sedimentological and general geological evidence for the shallow-water nature of the Hauptrogenstein Formation is very robust, if not irrefutable. Nevertheless, the great similarity between the Hauptrogenstein ophiuroid fauna and modern bathyal brittle star assemblages is a valid observation as well. At present, we can only speculate on the factors that made assemblages typically found in modern bathyal settings occur at much shallower depths during the Jurassic. In any case, the echinoderm fossil record suggests that the Hauptrogenstein ophiuroid fauna is not an exception is this respect (e.g. Gale 2011; Thuy et al. 2011). The crucial conclusion to be drawn here is that the bathymetrical distribution of the groups represented in the Hauptrogenstein ophiuroid fauna is controlled neither by water depth itself nor by a physical factor directly correlated with water depth, such as light penetration or current strength.

Unfortunately, our knowledge of the depth distribution patterns of modern organisms very rarely exceeds the level of mere observation of depth ranges (Gage \& Tyler 1991). This leaves almost endless possibilities for factors and combinations of factors controlling both present-day and ancient depth ranges. Matters become even more complicated when non-analogue situations come into play: changes in habitat preferences of organisms can occur over macroevolutionary time spans without necessarily being reflected by conspicuous morphological modifications. Alternatively, a new group can arise at some point in earth history and oust an older group from a particular habitat. Thus, present-day depth ranges cannot simply be extrapolated to ancient communities, no matter how striking similarities between assemblages are, as exemplified by the case of the Hauptrogenstein ophiuroids described herein.

Conspicuous as the above-made observations may be, a surprisingly high number of studies have relied entirely on a strictly actualistic approach, uncritically extrapolating present-day depth ranges to fossil communities (e.g. Bourbon et al. 1980; Charbonnier et al. 2007) and ichnofossil suites (e.g. Seilacher 1967). Ekdale (1988) rightly discouraged the use of trace fossil assemblages as indicators of water depth, stressing that water depth was not necessarily the critical factor controlling the distribution of such suites and that environmental shifts of certain trace fossils might have occurred through time. Palaeobathymetries based on skeletal remains, however, have remained 
surprisingly unimpressed by these warnings. An interesting example is the interpretation of the Middle Jurassic La Voulte Lagerstätte as a deep-sea setting on the basis of present-day depth ranges of siliceous sponges and stalked crinoids (Charbonnier et al. 2007). Insights into the factors controlling bathymetrical ranges of siliceous sponges and stalked crinoids are sparse but strongly suggest that water depth plays a subordinate role (e.g. Hess et al. 1999; Conway et al. 2001). As a result, the possibility of shallowwater occurrences under slightly different conditions than those prevailing in modern oceans cannot be excluded. Indeed, both siliceous sponges (Gammon et al. 2000) and stalked crinoids (e.g. Hess 1975) have been documented from ancient shallow shelf settings, challenging the reliability of the palaeodepth estimate of Charbonnier et al. (2007). Furthermore, the highly diverse crinoid fauna of La Voulte bears some resemblance to an equivalent fauna from the sponge facies of the Birmensdorf Member (Oxfordian) in Switzerland and therefore does not indicate a deep-sea setting (Hess in press). In addition, the presence of sponge tempestites (A. Wetzel \& C.A. Meyer, pers. obs.) in the Birmensdorf Member strongly supports a depositional environment above storm wave base, at c. 20-30 m water depth.

Pitfalls of direct depth range extrapolations become even more apparent when the broader implications of reconstructions come into play. In fact, the Middle Jurassic La Voulte section was interpreted as a deep-water setting on the basis of comparable modern bathyal sponges and crinoids (Charbonnier et al. 2007), and the presence of such deep-sea pycnogonids (Charbonnier et al. 2007), asteroids (Villier et al. 2009) and arthropods in general (Charbonnier et al. 2010) has subsequently been interpreted as evidence for a pre-Callovian deep-sea colonisation of these groups. This, of course, is a case of circular reasoning.

Many studies suffer from such pitfalls even by restricting extrapolations to fossil faunas which are stratigraphically and/or regionally close to the present-day calibration assemblages. Strictly speaking, however, stratigraphic and regional proximity, per se, do not necessarily imply a greater comparability. The key to an unproblematic extrapolation of bathymetrical ranges to ancient communities clearly lies in our understanding of the factors controlling them-in other words, in a mechanistic background which meaningfully explains why organisms must have lived at the same depth as they do in modern oceans.

\section{Mechanistic backgrounds for palaeodepth estimates}

One of the most obvious factors controlling the depth ranges of organisms is the availability of light. The intensity of sunlight directly correlates with water depth, and there is no reason to assume that this correlation has undergone major changes throughout the Phanerozoic. Thus, it can be safely assumed that the vast majority of phototrophic organisms invariably inhabited depths significantly shallower than $200 \mathrm{~m}$, i.e., the deepest known base of the photic zone being at $274 \mathrm{~m}$ according to Littler et al. (1985). Palaeodepth estimates based on benthic algae, zooxanthellate corals, large benthic foraminifera and other light-dependent organisms are robust (providing that the assemblages are autochthonous), because they are endorsed by a very clear mechanistic background: these organisms can only live at depths where there is sufficient light. One of the most remarkable studies in this respect is the palaeobathymetrical analysis of pelagic deposits of Late Jurassic age in the Apennines by Gill et al. (2004) using pennular corals. Both living and fossil representatives of the latter are known to display light-amplifying adaptations associated with highly sophisticated skeletal structures for suspension feeding, allowing them to colonise poorly illuminated zones (for details, see Insalaco 1996; Gill et al. 2004). This is a solid mechanistic background on the basis of which Gill et al. (2004) legitimately interpreted the occurrences of pennular corals on top of submarine highs and basin margins in the Tethyan Upper Jurassic as indicators of water depths close to the base of the photic zone.

Another convincing case of a mechanistic background for palaeodepth estimates are micro-endolithic ichnofossil assemblages (e.g. Radtke et al. 1997; Glaub 1999; Glaub et al. 2007). Microscopic borings, mostly in calcareous substrates such as shells, occur from intertidal to abyssal depths but their producers (cyanobacteria, sponges, red and green algae, fungi, foraminifera) show a non-random depth distribution primarily controlled by light intensity. Thanks to the direct correlation with illumination, and thus relative water depth (excluding exceptional cases such as shallowwater caves), a direct extrapolation of depth ranges of microendolith assemblages to fossil communities can be considered reasonably robust.

Mechanistic backgrounds based on depth-related factors other than illumination (density, hydrostatic pressure, water motion, temperature, etc.) are far more difficult to elaborate (e.g. Funnell 1967). This is in part due to the less obvious and often non-preservable adaptations of organisms to depth-related gradients in these factors. Another reason is that some of these factors, in contrast to illumination, are commonly subject to considerable regional variability irrespective of water depth. Protected shallowwater settings can display very low current strengths, and relatively high temperatures can occur in low latitude deepsea areas, for example. Therefore, any mechanistic, and thus truly reliable palaeobathymetrical, reconstructions below the photic zone are extremely difficult to achieve. This is not surprising, considering how little is known even 
of present-day deep-sea zonation patterns (Gage and Tyler 1991; Herring 2002).

To summarise, the Hauptrogenstein ophiuroid assemblage described herein is typical of modern bathyal settings, which, however, strongly contrasts with the generally accepted reconstruction of this unit as a very shallow, tideto storm-dominated carbonate platform deposit. This implies that water depth itself is not the critical factor which controlled the bathymetrical distribution of the ophiuroid groups involved. The present study is an example of the pitfalls of palaeobathymetries based on extrapolated present-day depth ranges of close relatives, and provides evidence to stress an important call for caution. No matter how great similarities between a fossil community and its modern analogue may be, and no matter how striking the present-day depth zonation patterns of the respective groups may seem, as long as we have no mechanistic background explaining why organisms are confined to a particular depth, we cannot simply extrapolate present-day depth ranges to ancient communities.

\section{Systematic palaeontology}

Class Ophiuroidea Gray, 1840

Order Ophiuridea Müller \& Troschel, 1840

Family Ophiomycetidae Verrill, 1899

Diagnosis: Ophiuroids with highly flexible disc, covered by thin scales and often dorsoventrally elongated or sack-like; radial shields strongly reduced or absent; arms capable of being raised vertically above disc; oral plates commonly beset with multiple rows of papillae; some forms with highly distinctive parasol-shaped arm spines.

Genus Ophiotholia Lyman, 1880

Ophiotholia aurora sp. nov, Fig. 3

Etymology: from "Aurora", the Roman goddess of the dawn, in reference to the early occurrence of the new species in the fossil record.

Holotype: M11202.

Diagnosis: Species of Ophiotholia with at least seven arm spines, and with ventral arm plates in contact in proximal arm segments.

Locus typicus: Schinznach, Canton Aargau, Switzerland.

Stratum typicum: Upper Hauptrogenstein Formation, Parkinsoni Zone, upper Bajocian.

Description: M11202 is an articulated specimen exposing the jaws and three nearly complete arms. Dorsal disc covered by arms. Thin, small, round scales discernible between proximal arm segments, suggesting a tall, coneshaped dorsal disc. Very few, small spines, four to five times longer than wide, scattered on dorsal disc scales. Jaws forming a conspicuous, widely gaping ring. Oral plates large and thick, height nearly equal to width, tallest proximally. Lateral and ventral edges of oral plates beset with numerous large papillae, at least ten per pair of oral plates; the proximalmost and lateralmost papillae blunt, spine like, four to five times longer than wide, slightly flattened; papillae becoming increasingly spatulate distalwards; distalmost pair of papillae very large and conspicuously paddle shaped, widest at the tip, with fine longitudinal striation. No teeth or apical papillae preserved. Dental plate entire, slender, wedge shaped, with single series of small tooth sockets. Ventral interradial areas narrow and mostly hidden by oral papillae; outlines of oral and adoral shields not seen.

Three arms exposed, nearly complete, raised vertically above disc. Arms $1.5 \mathrm{~mm}$ wide near base. Longest arm length preserved $14.6 \mathrm{~mm}$. Ventral arm plates large, with strongly concave lateral edges and gently convex distal edge; proximal ventral arm plates nearly as long as wide and with conspicuous longitudinal groove; distal ones slightly elongate and without groove. Ventral arm plate of proximalmost arm segment with deep proximal notch. Ventral arm plates in contact in proximal arm segments, and separated by lateral arm plates in median and distal segments. Tentacle pores very large, developed as interplate openings throughout the arm, covered by two blunt, spatulate scales in proximal and median arm segments, and probably by a single scale in distal segments. Lateral arm plates rather massive, slightly bulging distally, with conspicuous tentacle notch and protruding ventro-proximal tip. Ornament of outer surface consisting of coarse granulation or coarsely reticulate stereom. Proximal lateral arm plates taller than wide, distal ones slightly elongate. Row of spine articulations vertical, on slightly elevated distal portion of lateral arm plate. At least seven arm spines in proximal arm segments, slightly longer than one arm segment, flat; most arm spines of lanceolate outline: slender near the base, widest in the middle of the distal half, and with pointed tip. At least five arm spines in median segments and three in distal ones. Single, poorly preserved parasol-shaped spine discernible on one of the distalmost segments, nearly equalling half the length of an arm segment, attached to the middle part of the lateral arm plate. Dorsal side of arms not exposed.

\section{Remarks}

The most striking character of M11202 is that the arms are raised vertically above the disc. Only four extant 

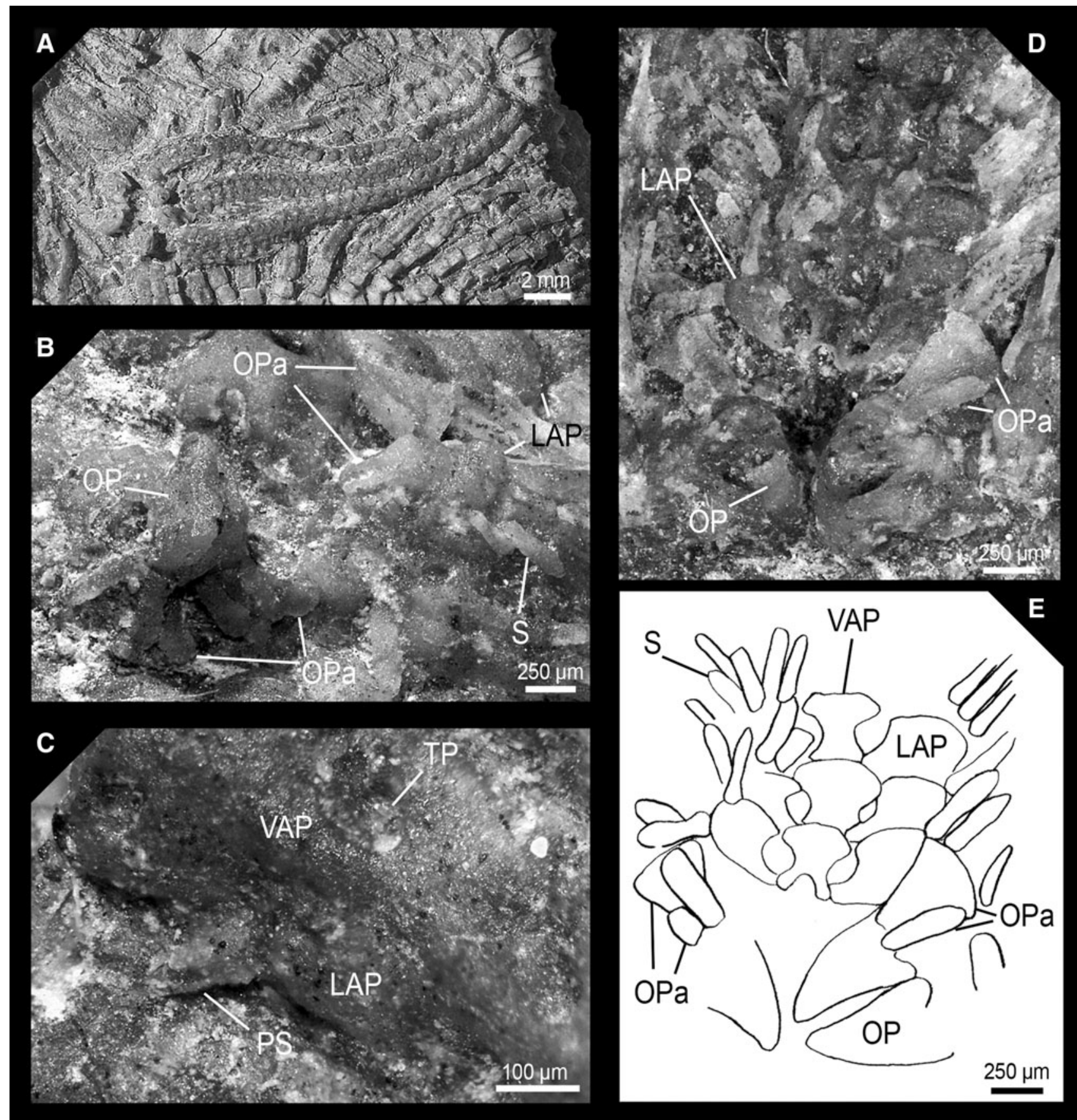

Fig. 3 Ophiotholia aurora sp. nov., M11202 (holotype) from the Upper Hauptrogenstein Formation, Parkinsoni Zone, upper Bajocian of Schinznach, Switzerland. a General aspect of specimen; $\mathbf{b}$ detail of ventral disc surface in ventro-lateral view; c detail of distal arm segments in ventral view showing poorly preserved parasol-shaped

ophiuroid genera are known to display this extraordinary feature: Ophiomyces Lyman, 1869, Ophiotholia Lyman, 1880, Ophiohelus Lyman, 1880 and Ophiothauma H.L. Clark, 1938. Of these, only Ophiotholia presents the combination of parasol-shaped spines in distal arm segments and oral papillae on both lateral and ventral edges spine; d detail of ventral disc with base of arm in ventral view; e drawing of d. $L A P$ lateral arm plate; $O P$ oral plate; $O P a$ oral papilla; $P S$ parasol-shaped spine; $S$ arm spine; $T P$ tentacle pore; $V A P$ ventral arm plate

of the oral plates seen in M11202. A total of six species are currently considered valid in the genus Ophiotholia (Stöhr \& O'Hara 2007), and similarities to the Middle Jurassic specimen are so strong that separation on the genus level would seem arbitrary rather than based on sound morphological differences. Particularly striking are 
the similarities in shape and arrangement of oral papillae to Ophiotholia spathifer (Lyman, 1879) and O. mitrephora H.L. Clark, 1910) and the presence of lanceolate arm spines to O. gibbosa Litvinova, 1992. Although assignment of the Hauptrogenstein specimen to an extant genus creates an excessively long stratigraphic generic range of some $160 \mathrm{myr}$, it effectively expresses the astonishing morphological similarity between the Jurassic and the extant forms. At the species level, M11202 differs from the modern species in the higher number of arm spines and i having ventral arm plates in contact in proximal arm segments. Since no comparable fossil form is known to date, we erect a new species for the Hauptrogenstein specimen.

The systematic position of the genera Ophiomyces, Ophiotholia, Ophiohelus and Ophiothauma has been a matter of debate ever since the discovery of the first representatives in the late nineteenth century. Lyman (1880) already pointed out that these forms stood quite apart from the other ophiuroids. Verrill (1899) proposed the new family Ophiomycetidae to include all forms with arms raised vertically over the disc known at that time, but Koehler (e.g. 1904, 1922) was the only one to adopt this view. In Clark's (1915) standard compilation, Ophiomyces, Ophiotholia and Ophiohelus were considered to be members of the Ophiacanthidae. This assignment has been generally adopted since (e.g. Fell 1960). Even following Paterson's (1985) revision and subdivision of the Ophiacanthidae, these genera were treated as ophiacanthids, albeit as members of a separate subfamily, the Ophiohelinae. For the first time, Martynov (2010) challenged the ophiacanthid affinities of the ophioheline genera, referring to fundamental differences in spine articulation morphology. He failed, however, to propose an alternative classification for the former Ophiohelinae.

The discovery of Ophiotholia in sediments as old as Middle Jurassic brings a new perspective to the debate. In fact, the astonishing similarity between the Jurassic and the modern forms suggests that former ophiohelines have been a morphologically highly distinctive and conservative lineage since at least 160 myr. Along with their unique morphology, unlike that of any other ophiuroid lineage, the long stratigraphic range of Ophiotholia strongly suggests that the former ophiohelines should be separated from the remaining ophiuroids on a higher level than subfamily. We, therefore, propose to resurrect Verrill's (1899) Ophiomycetidae to accommodate Ophiomyces, Ophiotholia, Ophiohelus and Ophiothauma, pending a revision of ophiuroid phylogenies to substantiate further the position and the level of separation of the lineage with respect to other ophiuroid groups.
Family Ophiacanthidae Ljungman, 1867

Genus Hanshessia nov.

Etymology: named in honour of Hans Hess (Binningen, Switzerland) for his continuing contributions to echinoderm palaeontology, his pioneering work on the Hauptrogenstein echinoderms and for introducing both authors to the ins and outs of ophiuroid palaeontology.

Type, and only known, species: Hanshessia trochitophila sp. nov.

Diagnosis: Ophiacanthid ophiuroid with large, near-circular radial shields, numerous, granule- to stump-like oral papillae covering the oral plates and adoral shields in multiple rows, relatively small tentacle pores covered by a single, very large, leaf-like scale pointing to the arm midline and perpendicular to the axis of the arm, up to 11 arm spine articulations increasing in size dorsalwards.

Hanshessia trochitophila sp. nov.

Fig. 4

Synonymy

1985 Ophiacantha? cf. constricta Hess (1966): Hess \& Holenweg (1985), pp. 164-166, fig. 17.

Etymology: from "trochos", Greek for wheel and sealily and the Latin suffix "philus", meaning "loving", in reference to the fact that the new taxon is found in close association with stalked crinoids.

Holotype: M9765.

Additional material: M11203.

Diagnosis: as for genus.

Locus typicus: Quarry Egg near Auenstein, Canton Aargau, Switzerland.

Stratum typicum: Upper Hauptrogenstein Formation, Parkinsoni Zone, upper Bajocian. Description of holotype: M9765 is a fragment of an articulated disc with two arms preserving proximal and, in one case, median segments. Originally on a large slab with articulated individuals of Pentacrinites dargniesi Terquem \& Jourdy and exposing the dorsal side only, the ophiuroid specimen was detached from its matrix to enable examination of both dorsal and ventral sides. 


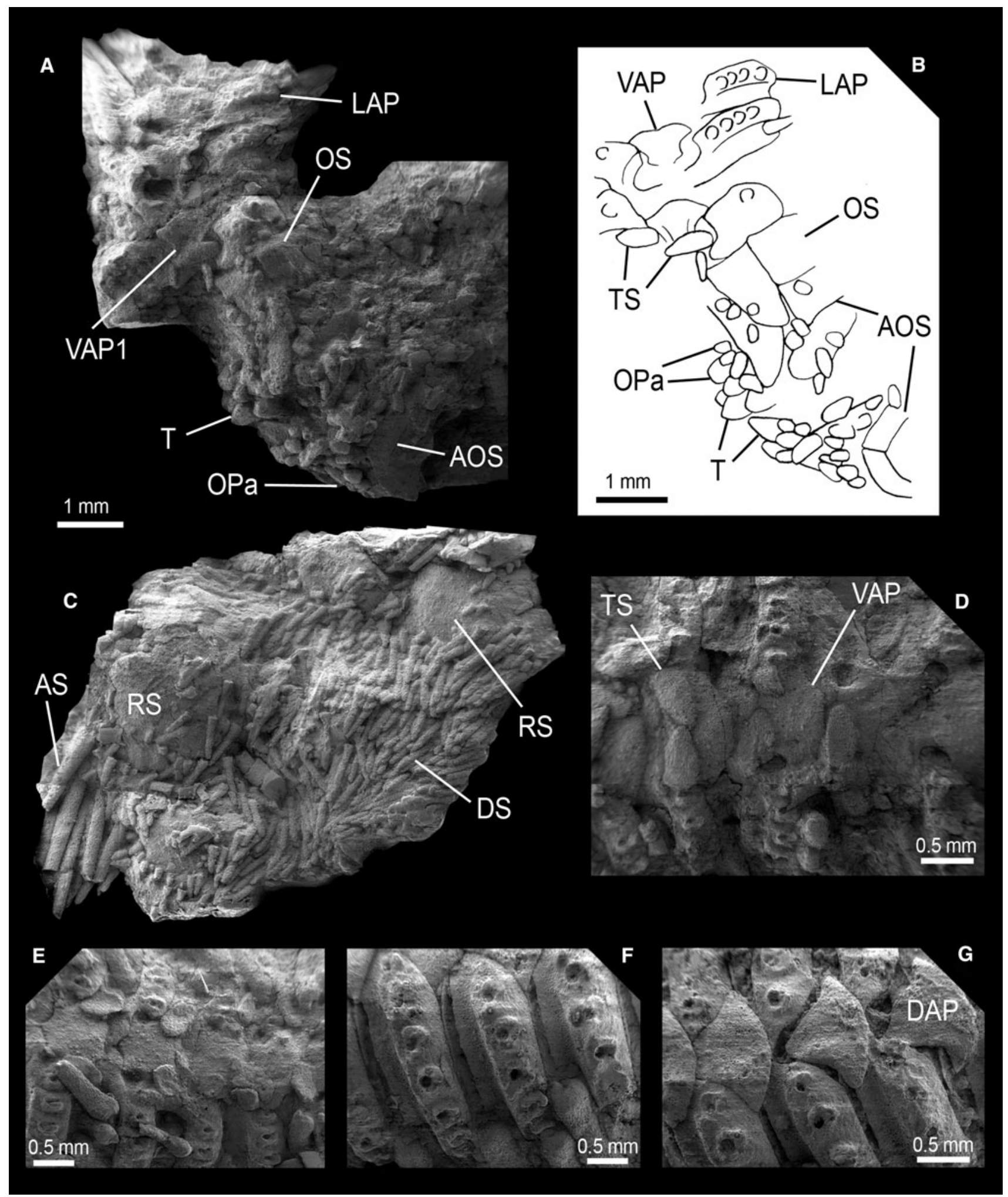

Fig. 4 Hanshessia trochitophila gen. et sp. nov., M9765 (holotype) from the Upper Hauptrogenstein Formation, Parkinsoni Zone, upper Bajocian of Quarry Egg near Auenstein, Switzerland. a Disc fragment in ventral view; $\mathbf{b}$ drawing of $\mathbf{a}$; $\mathbf{c}$ disc fragment in dorsal view; d proximal arm segments in ventral view; e median arm fragments in ventral view; f proximal arm segments in dorso-lateral view; g proximal arm segments in dorsal view. AOS adoral shield; $A S$ arm spine; $D A P$ dorsal arm plate; $D S$ disc spine; $L A P$ lateral arm plate; $O P a$ oral papilla; $O P$ oral plate; $O S$ oral shield; $R S$ radial shield; $T$ tooth; $T S$ tentacle scale; VAP ventral arm plate; VAP1 first ventral arm plate 
Reconstructed disc diameter $15.4 \mathrm{~mm}$. Disc originally circular in outline, dorsal side covered by small, round plates, very densely beset with large, conical spines, up to eight times longer than wide, bearing minute thorns. Spines longest in disc centre, becoming shorter towards disc edge. Radial shields stout, nearly circular, about one-third of disc radius, completely separated by round disc scales, surrounded and partially covered on their margins by short disc spines and stumps, two to four times longer than wide. Ventral interradial areas with small, round disc scales similar to those of the dorsal disc, beset with disc stumps and spines, two to five times longer than wide. Jaws nearly as wide as long, densely covered laterally and ventrally with multiple rows of small stump- to granule-like papillae, at most two times longer than wide, longest near apex of jaws. Single major apical papilla, triangular to tetrahedral, several times larger than oral papillae, followed dorsally by single row of slightly larger, pointed, tongue-like to tetrahedral teeth. Adoral shields relatively short, approximately two times longer than wide, abutting proximally, not separating oral shield from first lateral arm plate, covered by oral papillae. Oral shield arrow shaped, with slightly obtuse proximal angle and strongly concave latero-distal edges, slightly wider than long.

Two arm fragments visible, preserving proximal and median segments. Ventral arm plates slightly wider than long, widest distally, with strongly convex distal edge and notched lateral edges, separated by lateral arm plates on all visible arm segments. Tentacle pores medium sized, smaller than two times the width of the ventral arm plate, covered by a single very large, leaf-like scale pointing to the arm midline and perfectly perpendicular to the axis of the arm. Three proximalmost ventral arm plates approximately two times wider than long, grooved proximally. Dorsal arm plates fan- to bell-shaped, slightly wider than long, with pointed proximal angle, slightly concave lateral edges and convex distal edge; abutting on all observable arm segments except for the distalmost preserved (median arm segments). Lateral arm plates several times taller than wide, strongly arched, ventral tip protruding and with conspicuous tentacle notch; outer surface of proximal and median lateral arm plates without conspicuous spurs on the proximal edge or ornament; large, ear-shaped spine articulations with sigmoidal fold in continuous row on large, strongly elevated ridge on distal part of lateral arm plate; ridge only weakly protruding on ventral side of the arms; dorsalmost or second-dorsalmost spine articulation largest; progressive ventralward decrease in size of spine articulations and gaps separating them; at least 10 spine articulations in proximal and median arm segments. Arm spines very large, cylindrical, pointed, finely striated, as long as three to four arm segments; ventral arm spines much smaller than dorsal ones, slightly curved but not developed into hooks on observable arm segments.

Paratype supplements and variation

M11203 is a semi-articulated disc (dd: $10.1 \mathrm{~mm})$ exposing the dorsal surface and preserving proximal portions of at least three arms. The morphology of the dorsal disc and arm skeleton agrees well with that of the holotype. Due to the partial disintegration of the skeleton, vertebrae are exposed and show large, vertical, wing-like muscular fossae and streptospondylous articulation pegs.

\section{Remarks}

The presence of a single row of teeth in combination with large, ear-shaped spine articulations presenting a sigmoidal fold and positioned on a strongly elevated ridge unquestionably places these specimens in the family Ophiacanthidae. Within this family, the specimens fall into the group including the former ophioplinthacines and ophiochondrines, characterised by well-developed disc plates, large radial shields and relatively small tentacle pores, and grouping on top of the large clade of nestled ophiacanthid lineages recently found by Thuy et al. (2012). The combination of large, near-circular radial shields and numerous small, granule- to stump-like oral papillae densely covering the oral plates and adoral shields in multiple rows is unique among these lineages. The peculiar, large tentacle scales pointing to the arm midline are not found in any other ophiacanthid genus either, thus underscoring the unique status of this material. We therefore erect the new genus Hanshessia within the Ophiacanthidae to accommodate the Hauptrogenstein specimens.

A number of Jurassic ophiacanthid species have been described on the basis of dissociated lateral arm plates (Thuy et al. (2012)). Among these, the lateral arm plates of Ophiacantha? constricta Hess, 1966 from the Oxfordian of Switzerland and France share the greatest similarities with the Hauptrogenstein specimens. Hess and Holenweg (1985), who mentioned the above-mentioned specimens for the first time, already noted these similarities and tentatively assigned them to Ophiacantha? cf. constricta. In the lateral arm plates of the Hauptrogenstein specimens, however, the spine articulation ridge protrudes much less strongly ventralwards than in Ophiacantha? constricta, and the spine articulations show a slight but clear dorsalward increase in size. Based on these differences, we consider the Hauptrogenstein to be a distinct species. It cannot be decided on the basis of the material available whether the Hauptrogenstein species and Ophiacantha? constricta are congeneric. In spite of the similarities in lateral arm plate 
morphology, transfer of $O . ?$ constricta to the new genus Hanshessia appears to be premature.

\section{Genus Alternacantha nov}

Etymology: name composed of "alternans", Latin for alternating, and "acantha", the name of a Greek nymph, literally translating into "thorny", in reference to the alternating position of the dorsalmost arm spine articulation.

Type, and only known, species: Alternacantha occulta sp. nov.

Diagnosis: Large ophiacanthid with arms displaying a conspicuous alternating pattern in the position of the dorsalmost arm spine articulation, varying between close to the remaining spine articulations and separated by the latter by a large gap; arm spines as long as three arm segments; radial shields thin, oval, as long as one-third of the disc radius or slightly longer; dorsal disc covered by minute spherical granules.

\section{Alternacantha occulta sp. nov.}

Figs. 5, 6

Etymology: from "occultus", Latin meaning "well hidden" in reference to the new species that is almost invisible amongst the dense colonies of crinoids.

Synonymy:

1972 Dermocoma wrighti Hess 1964: Hess, pp. 36-39, figs. 39-41; pl. 13, fig. 1.

1985 Dermocoma wrighti Hess 1964: Hess \& Holenweg, p. 157 , fig. 10.

Etymology:

Holotype: M9761.

Additional material: M9599, M9384/1-2 and M11200 (paratypes); M11205 and M9527.

Diagnosis: as for genus.

Locus typicus: Sichtern near Liestal, Canton Basel-Country, Switzerland.

Stratum typicum: Varians beds, middle Bathonian.

Occurence: Lower Hauptrogenstein Formation, Niortense Zone; upper Bajocian; Upper Hauptrogenstein Formation, Parkinsoni Zone, upper Bajocian; Klingnau Formation,
Parkinsoni Zone, upper Bajocian; Varians beds, middle Bathonian.

Description of holotype: M9761 (Fig. 5) is an articulated specimen preserving four near-complete arms and exposing the ventral side. Dorsal side of disc embedded in matrix $(\mathrm{dd}=6.6 \mathrm{~mm})$. Disc nearly circular in outline. Ventral interradial areas covered by very small, thin scales. Jaws slightly wider than long, beset with a single continuous row of seven leaf-like oral papillae: three to four large, flat, blunt distal oral papillae followed by a single slightly smaller blunt papilla and two to three much smaller, pointed proximal papillae. Tip of jaws with two to three apical papillae similar in size and outline to the middle, medium-sized oral papilla. Teeth of similar size but coneshaped and pointed. Oral shields very large, wider than long, nearly oval with slightly pointed proximal edge. Adoral shields long and relatively narrow, separating oral shield from lateral arm plates; proximal tips of adoral shields relatively broad, blunt, in contact. Few scattered granules on oral shields, adoral shields and jaws.

Four arms exposed, entangled with stalks and cirrals of the isocrinid crinoid Hispidocrinus leuthardti (de Loriol) and arms of Ophiomusium ferrugineum. Longest arm preserved almost as long as three times the disc diameter. Ventral arm plates very large, nearly as long as wide (proximal and median arm segments) to slightly elongate (distal ones), widest distally, with pointed proximal edge, gently notched lateral edges and evenly convex distal edge. Ventral arm plates abutting on all observable arm segments. Tentacle openings smaller than half the width of the ventral arm plate, covered by two short, flat, leaf-like tentacle scales on all observable arm segments. Lateral arm plates taller than wide in proximal segments, elongate in distal ones; well-developed constriction, resulting in bulging distal portion of lateral arm plate; ventral portion strongly protruding, with large tentacle notch; outer surface with vertical striation, best developed near spine articulations, fading into finely reticulate stereom towards proximal edge of lateral arm plate; at least two moderately well-defined, prominent and protruding spurs on proximal edge of lateral arm plate; four spine articulations in all observable arm segments, freestanding on bulging distal portion of lateral arm plate, encompassed by gentle notches interrupting the vertical striation of the outer surface; lateral arm plates in contact ventrally underneath ventral arm plates on all observable arm segments; spine articulations large, ear shaped with sigmoidal fold, dorsalward increase in size of spine articulations; position of dorsalmost spine articulation variable, closer to remaining spine articulations or separated from the latter by a considerable gap, irregularly alternating between segments. Arm spines large, cylindrical and almost 

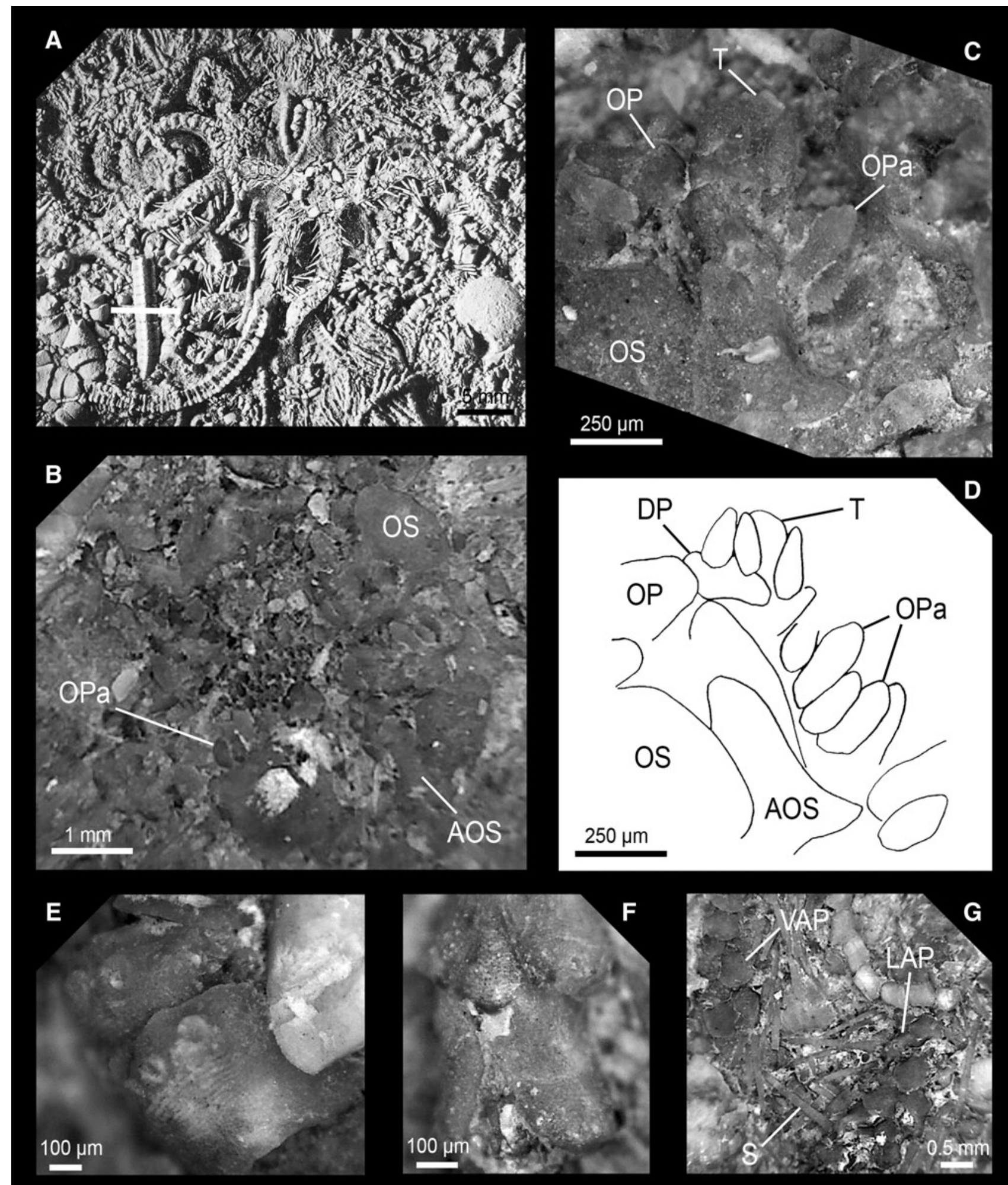

Fig. 5 Alternacantha occulta gen. et sp. nov., M9761 (holotype) from the Varians beds, middle Bathonian of Sichtern near Liestal, Switzerland. a General aspect of specimen from Hess and Holenweg (1985); b detail of oral skeleton; c detail of jaw; d drawing of $\mathbf{c}$; e median arm segments in dorso-lateral view; $\mathbf{f}$ distal arm segments in dorsal view; $\mathbf{g}$ median arm segments in ventral view. $A O S$ adoral shield; $D P$ dental plate; $L A P$ lateral arm plate; $O S$ oral shield; $O P$ oral plate; $O P a$ oral papilla; $S$ arm spine; $T$ tooth; $V A P$ ventral arm plate 


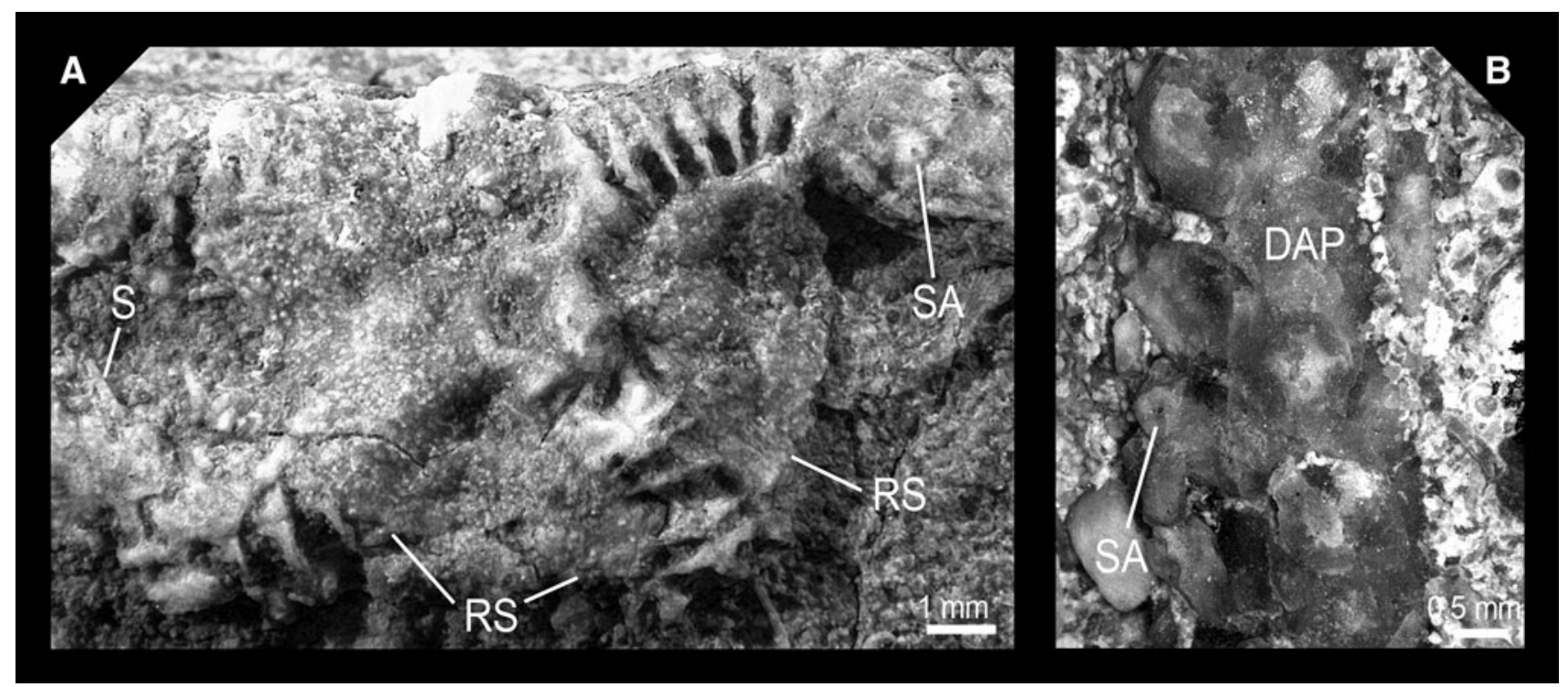

Fig. 6 Alternacantha occulta gen. et sp. nov. from the Upper Hauptrogenstein, Parkinsoni Zone, upper Bajocian of Schinznach, Switzerland. a M112000 (paratype), disc exposing dorsal side;

as long as three arm segments. Dorsal arm plates exposed on distal segments only, fan shaped, more than two times longer than wide, with acutely pointed proximal angle and strongly convex distal edge, separated by lateral arm plates, slightly arched and with fine transverse striation.

\section{Paratype supplements and variation}

M9599 [amply figured by Hess (1972)] is a fragment of an articulated disc (reconstructed $\mathrm{dd}=18.6 \mathrm{~mm}$ ) completely free of matrix and preserving the ring of jaws and two arm bases. The ventral disc plating agrees well with that of the holotype. Ventral interradial areas much better preserved, densely covered by minute granules. Jaws beset with a single continuous row of nine to ten oral papillae, including five large, flat, leaf-like distal ones, two medium-sized blunt middle ones and two to three small pointed proximal ones. First ventral arm plate about half the size of successive ones, wider than long, with rounded proximal and lateral edges and pointed distal edge. Following three ventral arm plates with proximal, protruding keel lined on both sides by grooves, best developed on second ventral arm plates, grooves gradually shallowing in third and fourth ventral plates and completely lacking in successive ones. Five arm segments observable, all incorporated into disc, best preserved arm broken at disc edge. Five spine articulations on fourth and fifth arm segments.

Dorsal side poorly preserved. Dorsal disc plates very thin but outline not discernible. One radial shield preserved, oval, slightly longer than one-third of the disc radius. Dorsal disc including radial shield densely covered by small, spherical granules. b M9384/X (paratype), proximal arm fragments in dorsal view. $D A P$ dorsal arm plates; $R S$ radial shields; $S$ arm spine; $S A$ spine articulation

M9384/1-2 (Fig. 6b) is a slab containing two large arm fragments, one approximately $65 \mathrm{~mm}$ long and exposing the ventral and lateral sides, and one largely covered by matrix and exposing the dorsal side of several proximal to median segments. Ventral and lateral arm morphology agrees well with that of the holotype. Four arm spine articulations on all observable segments. Position of dorsalmost spine articulation alternating between close to the remaining spine articulations and separated from the latter by a large gap. Proximal and median dorsal arm plates in contact, slightly longer than wide, bell- to fan-shaped, with acute proximal angle; straight to slightly convex lateral edges and convex to pointed distal edge, with fine transverse striation; proximal dorsal arm plates clearly arched longitudinally, median ones only slightly arched.

M11200 (Fig. 6a) is an articulated specimen exposing the dorsal side and preserving a major portion of the disc $(\mathrm{dd}=10.2 \mathrm{~mm})$ and three arm fragments, the longest of which measures $30.4 \mathrm{~mm}$ in length. Overall morphology agrees well with other type specimens. Disc preserving several radial shields in place, oval, approximately 1.8 times longer than wide, equalling one-third of the disc radius, widely separated and apparently covered by fewer granules than remaining disc plates. Outline of jaws discernible underneath relatively thin disc plates impressed on jaws; oral plates relatively short and devoid of lateral wings.

\section{Remarks}

The above-described specimens are unquestionably assignable to the Ophiacanthidae on account of the large, 
ear-shaped spine articulations positioned on an elevated ridge, the lack of tooth papillae and oral plates that are devoid of lateral wings. Although the exact phylogenetic position within the Ophiacanthidae requires further research, the specimens fall within the group composed of former ophioplinthacine and ophiochondrine genera characterised by well-developed disc plates, relatively large and radial shields which are not bar like, and small tentacle pores (Thuy et al. 2012). Within this group, only Ophiocamax displays a slight alternation in the position of the dorsalmost spine articulation. The main alternation pattern in this genus, however, concerns the position of the largest spine articulation, which is alternately the dorsalmost or the second or third dorsalmost. In addition, Ophiacamax displays spine-like oral papillae arranged in multiple rows and erect tentacle scales enclosing the two or three basalmost tentacle pores. The above-described specimens thus clearly differ from any known extant ophiacanthid.

Striking similarities in disc morphology are shared with the type specimens of Dermocoma wrighti Hess, 1964 from the Bathonian of England. The latter differ mainly in having adoral shields with conspicuously pointed proximal tips and slightly smaller oral shields. The arm skeleton, in contrast, is markedly different. The English specimens display much less strongly bulging distal portions of the lateral arm plates, five spine articulations even in segments not incorporated into the disc, ventral arm plates with a near-straight distal edge, small spine-like tentacle scales in median to distal segments, much shorter arm spines, and, most importantly, no alternation in the position of the dorsalmost spine facet. In spite of the admittedly strong similarities in disc plating, the utterly different arm morphologies, in particular the alternating spine articulation pattern, justify the creation of a new genus.

The close resemblance in disc morphology between Dermocoma wrighti and the present specimens prompted Hess (1972) and Hess and Holenweg (1985) to place their Hauptrogenstein material in that species. While this is most probably true for the specimen in Fig. 2 of Hess and Holenweg (1985), in view of the short arm spines and gently bulging distal portions of the lateral arm plates, all other specimens figured and described by Hess (1972) and Hess and Holenweg (1985) are assignable to the new genus. Examination of the type material of Dermocoma wrighti housed at the Natural History Museum in London (UK) confirmed the presence of ear-shaped spine articulations displaying a sigmoidal fold. This clearly places $D$. wrighti in the extant family Ophiacanthidae. As a consequence, the family Dermocomidae, as introduced by Hess (1972), should be suppressed.

As already noted by Hess (1972), the specimens described here share a remarkable similarity, especially in terms of alternating spine articulation pattern, with arm fragments described by d'Orbigny (1850) as Ophiurella bispinosa and later redescribed by de Loriol (1872) as Ophiurella royeri, probably on the basis of the same material (Hess 1972). An allegedly closely similar individual from the Oxfordian of France was described by Hess (1960) and assigned to the same species. Examination of Hess's specimen deposited in the Naturhistorisches Museum Basel suggests that it most probably belongs to the new genus Alternacantha. Yet, transfer of Ophiurella bispinosa (and its probable synonym O. royeri) to Alternacantha awaits re-examination of d'Orbigny's type material.

Acknowledgments We wish to thank Walter Etter and Oliver Schmidt (Naturhistorisches Museum Basel, Switzerland) for granting access to the Hauptrogenstein ophiuroid material, Hans Hess (Binningen, Switzerland) for sharing his long experience with working on the Hauptrogenstein Formation and its echinoderm fauna, Toshihiko Fujita (Tokyo, Japan) for the generous loan of comparative specimens of the rare extant genus Ophiotholia, Dorothea Hause-Reitner and Wolfgang Dröse (Göttingen, Germany) for assistance with scanning electron microscopy, and the reviewers John W.M. Jagt and an anonymous reviewer, whose comments greatly improved an earlier version of this manuscript.

\section{References}

Allen, J. R. L. (1967). Depth indicators of clastic sequences. Marine Geology, 5, 429-446.

Ausich, W.I. (2001). Echinoderm taphonomy. In M. Jangoux \& J.M. Lawrence (Eds.), Echinoderm studies 6 (pp. 171-227). Rotterdam: Balkema.

Bathurst, R. G. C. (1967). Depth indicators in sedimentary carbonates. Marine Geology, 5, 447-471.

Benson, R. H. (1984). Estimating greater paleodepths with ostracods, especially in past thermospheric oceans. Palaeogeography, Palaeoclimatology, Palaeoecology, 48, 107-141.

Boehm, G. (1899). Ein Beitrag zur Kenntnis fossiler Ophiuren. Bericht der Naturforschenden Gesellschaft zu Freiburg i. Br., 4, 232-287.

Boltovskoy, E. (1965). Los foraminiferos recientes. Buenos Aires: Eudeba.

Bourbon, M., De Graciansky, P.-C., \& Roux, M. (1980). Indices bathymétriques fournis par les Crinoïdes pédonculés sur le bord de la marge téthysienne (Briançonnais et Subbriançonnais au Jurassique et au Crétacé). Bulletin de la Société géologique de France, 22, 713-718.

Brett, C.E., Moffat, H.A. \& Taylor, W.L. (1997). Echinoderm taphonomy, taphofacies and Lagerstätten. In J. A. Water \& C. G. Maples (Eds.), Geobiology of Echinoderms. Paleontology Society Papers 3 (pp. 147-190). Pittsbutgh: Carnegie Museum.

Brett, C. E., \& Seilacher, A. (1991). Fossil Lagerstätten: a taphonomic consequence of event sedimentation. In G. Einsele, et al. (Eds.), Cycles and Events in Stratigraphy (pp. 283-297). New York: Springer.

Charbonnier, S., Vannier, J., Gaillard, C., Bourseau, J. P., \& Hantzpergue, P. (2007a). The La Voulte Lagerstätte (Callovian): evidence for a deep water setting from sponge and crinoid communities. Palaeogeography, Palaeoclimatology, Palaeoecology, 250, 216-236.

Charbonnier, S., Vannier, J., Hantzpergue, P., \& Gaillard, C. (2010). Ecological significance of the arthropod fauna from the Jurassic 
(Callovian) La Voulte Lagerstätte. Acta Palaeontologica Polonica, 55, 111-132.

Charbonnier, S., Vannier, J., \& Riou, B. (2007b). New sea spiders from the Jurassic La Voulte-sur-Rhône Lagerstätte. Proceedings of the Royal Society B, 274, 2555-2561.

Clark, H. L. (1910). A new ophiuran from the West Indies. Proceedings of the U.S. Museum of Natural History, 37, 665-666.

Clark, H. L. (1911). North Pacific Ophiurans in the collection of the Unites States National Museum. Bulletin of the United States National Museum, 75, 1-302.

Clark, H.L. (1915). Catalogue of Recent ophiurans. Memoirs of the Museum of Comparative Zoology, 25, 163-376, 20 pls.

Clark, H. L. (1938). Echinoderms from Australia. An account of collections made in 1929 and 1932. Memoirs of the Museum of Comparative Zoology at Harvard College, 55, 1-597.

Conway, K. W., Krautter, M., Barrie, J. V., \& Neuweiler, M. (2001). Hexactinellid sponge reefs on the Canadian continental shelf: a unique „living fossil“. Geoscience Canada, 28, 71-78.

Davis, R. A. (1977). Principles of oceanography. Reading: AddisonWesley.

de Loriol, P. (1872). Description géologique et paléontologique des étages jurassiques supérieurs de la Haute-Marne. Mémoires de la Société linnéenne de Normandie, 16, 1-542.

Ekdale, A. A. (1988). Pitfalls of paleobathymetric interpretations based on trace fossil assemblages. Palaios, 3, 464-472.

Fell, H. B. (1960). Synoptic keys to the genera of Ophiuroidea. Zoology Publications from Victoria University of Wellington, 26, 1-44.

Flügel, E. (2004). Microfacies of carbonate rocks. Berlin: Springer.

Funnell, B. M. (1967). Foraminifera and radiolarians as depth indicators in the marine environment. Marine Geology, 5, $333-347$.

Gage, J. D., \& Tyler, P. A. (1991). Deep-sea biology: a natural history of organisms at the deep-sea floor. Cambridge: Cambrige University Press.

Gale, S. S. (2011). Asteroidea (Echinodermata) from the Oxfordian (Late Jurassic) of Savigna, Département du Jura, France. Swiss Journal of Palaeontology, 130, 69-89.

Gammon, P. R., James, N. P., \& Pisera, A. (2000). Eocene spiculites and spongiolites in southwestern Australia: not deep, not polar, but shallow and warm. Geology, 28, 855-858.

Gill, G. A., Santantonio, M., \& Lathuilière, B. (2004). The depth of pelagic deposits in the Tethyan Jurassic and the use of corals: an example from the Apennines. Sedimentary Geology, 166, 311-334.

Glaub, I. (1999). Paleobathymetric reconstructions and fossil microborings. Bulletin of the Geological Society of Denmark, 45, 143-146.

Glaub, I., Golubic, S., Gektidis, M., Radtke, G., \& Vogel, K. (2007). Microborings and microbial endoliths: Geological implications. In W. Miller III (Ed.), Trace Fossils (pp. 368-381). Amsterdam: Elsevier.

Gonzalez, R. (1993). Die Hauptrogenstein-Formation der Nordwestschweiz (mittleres Bajocien bis unteres Bathonien), Unpublished Ph. D. Basel: University of Basel. 190 pp.

Gonzalez, R. (1996). Response of shallow-marine carbonate facies to third-order and high-frequency sea-level fluctuations: Hauptrogenstein Formation, northern Switzerland. Sedimentary Geology, 102, 111-130

Gonzalez, R., \& Wetzel, A. (1996). Stratigraphy and paleogeography of the Hauptrogenstein and Klingnau formations (middle Bajocian to late Bathonian), northern Switzerland. Eclogae Geologicae Helvetiae, 89, 695-720.

Gray, J. E. (1840). A synopsis of the genera and species of the class Hypostoma (Asterias Linnaeus). Annals of the Magazine of Natural History, 6(175-184), 275-290.
Guille, A. (1981). Echinodermes: Ophiurides. Mémoires ORSTOM, 91, 413-456.

Herring, P. (2002). The biology of the deep ocean. New York: Oxford University Press.

Hess, H. (1960). Ophiurenreste aus dem Malm des Schweizer Juras und des Départements Haut-Rhin. Eclogae Geologicae Helvetiae, 53, 385-421.

Hess, H. (1964). Die Ophiuren des englischen Jura. Eclogae Geologicae Helvetiae, 57, 756-801.

Hess, H. (1966). Mikropaläontologische Untersuchungen an Ophiuren V: Die Ophiuren aus dem Argovien (unteres Ober-Oxford) vom Guldental (Kt. Solothurn) und von Savigna (Dépt. Jura). Eclogae Geologicae Helvetiae, 59, 1025-1063.

Hess, H. (1972). Eine Echinodermen-Fauna aus dem mittleren Dogger des Aargauer Juras. Schweizerische Paläontologische Abhandlungen, 92, 1-87.

Hess, H. (1975). Die Echinodermen des Schweizer Juras. Veröffentlichungen aus dem Naturhistorischen Museums Basel, 8, 1-130.

Hess, H. (2011). Treatise on Invertebrate Paleontology, Part T, Revised, Echinodermata 2, volume 3, Crinoidea Articulata. Lawrence, Kansas: KU Paleontological Institute, University of Kansas.

Hess, H., Ausich, W., Brett, C. E., \& Simms, M. J. (Eds.). (1999). Fossil Crinoids. New York: Cambridge University Press.

Hess, H., \& Holenweg, H. (1985). Die Begleitfauna auf den Seelilienbänken im mittleren Dogger des Schweizer Juras. Tätigkeitsberichte der Naturforschenden Gesellschaft Baselland, 33, 141-177.

Hess, H., \& Meyer, C. A. (2008). A new ophiuroid (Geocoma schoentalensis sp. nov.) from the Middle Jurassic of northwestern Switzerland and remarks on the family Aplocomidae Hess 1965. Swiss Journal of Geosciences, 101, 29-40.

Hofmann, K. (1996). Die mikro-endolithischen Spurenfossilien der borealen Oberkreide Nordwest-Europas. Geologisches Jahrbuch, A136, 1-153.

Insalaco, E. (1996). Upper Jurassic microsolenid biostromes of northern and central Europe: facies and depositional environment. Palaeogeography, Palaeoclimatology, Palaeoecology, 121, 169-194.

Irimura, S. (1982). The brittle-stars of Sagami Bay. Japan: Biological Laboratory Imperial Household.

Koehler, R. (1904). Ophiures des mers profondes. Siboga-Expeditie, $45,1-176$.

Koehler, R. (1922). Ophiurans of the Philippine Seas and adjacent waters. Smithsonian Institution, United States National Museum, $100,1-486$.

Kutscher, M. \& Jagt, J.W.M. (2000). Early Maastrichtian ophiuroids from Rügen (northeast Germany) and Møn (Denmark). In J.W.M. Jagt, Late Cretaceous-Early Palaeocene echinoderms and the $K / T$ boundary in the southeast Netherlands and the northeast Belgium-part 3: Ophiuroids (pp. 45-107).

Littler, M. M., Littler, D. S., Blair, S. M., \& Norris, J. N. (1985). Deepest known plant life is discovered on an uncharted seamount. Science, 227, 57-59.

Litvinova, N. M. (1992). Revision of the genus Ophiotholia (Echinodermata, Ophiuroidea). Zoologichesky Zhurnal, 71, 47-57. (In Russian).

Ljungman, A. V. (1867). Ophiuroidea viventia huc usque cognita enumerat. Översigt af Kongliga Vetenskaps-Akademiens Förhandlingar, 23, 303-336.

Lyman, T. (1869). Preliminary report on the Ophiuridea and Astrophytidae dredged in deep water between Cuba and the Florida Reef, by L.F. de Pourtalès, Assist. U.S. Coast Survey. Bulletin of the Museum of Comparative Zoology, Harvard University, 1, 309-354.

Lyman, T. (1879). Ophiuridae and Astrophytidae of the "Challenger" expedition. Part II. Bulletin of the Museum of Comparative Zoology at Harvard College, 6, 17-83, pls. 1-10. 
Lyman, T. (1880). A structural feature hitherto unknown among Echinodermata found in deep-sea ophiurans. Anniversary Memoirs of the Boston Society of Natural History, 1880, 1-12, pls $1-2$.

Lyman, T. (1882). Ophiuroidea. Report on the Scientific Results of the Voyage of the Challenger, Zoology, 5, 1-385.

Lyman, T. (1883). Reports on the results of dredging, under the supervision of Alexander Agassiz, in the Caribbean Sea (1878-79), and on the east coast of the United States, during the summer of 1880 , by the U.S. coast survey steamer "Blake", commander J.R. Bartlett, U.S.N., commanding. XX. Report on the Ophiuroidea. Bulletin of the Museum of Comparative Zoology at Harvard College, 10, 227-287.

Martynov, A. (2010). Reassessment of the classification of the Ophiuroidea (Echinodermata), based on morphological characters. I. General character evaluation and delineation of the families Ophiomyxidae and Ophiacanthidae. Zootaxa, 2697, 1-154.

Mégnien, C. (Ed.) (1980). Synthèse géologique du Bassin de Paris, Atlas. Mémoires du Bureau de Recherches géologiques et minières, vol. 2, p. 102.

Menzies, R. J., George, R. Y., \& Rowe, G. T. (1973). Abyssal environment and ecology of the world oceans. New York: Wiley.

Meyer, C.A. (1987). Palökologie, Biofazies und Sedimentologie von Seeliliengemeinschaften aus dem unteren Hauptrogenstein des Nordwestschweizer Jura. Unpublished PhD Thesis, University of Bern, 83 pp.

Meyer, C. A. (1988). Paläoökologie, Biofazies und Sedimentologie von Seelilien-Gemeinschaften aus dem Unteren Hauptrogenstein des Nordwestschweizer Jura. Revue de Paléobiologie, 7(2), 359-433.

Meyer, C. A. (1990). Depositional environment and palaeoecology of crinoid-communities from the Middle Jurassic Burgundy-Platform of Western Europe. In C. De Ridder, P. Dubois, M.-C. Lahaye, \& M. Jangoux (Eds.), Echinoderm Research (pp. 25-31). Rotterdam: Balkema.

Müller, J., \& Troschel, F. H. (1840). Über die Gattungen der Ophiuren. Archiv für Naturgeschichte, Berlin, 6, 327-330.

Oberhänsli, H. (1984). Stabile Isotopen: Hilfsmittel für die Paläobathymetrie. Paläontologische Kursbücher, 2, 96-103.

Orbigny, A. d‘(1850). Prodrome de paléontologie stratigraphique universelle des animaux mollusques et rayonnés faisant suite au cours élémentaire de paléontologie et de géologie stratigraphique, 2, 1-428. Paris: Masson.

Paterson, G. L. J. (1985). The deep-sea Ophiuroidea of the North Atlantic Ocean. Bulletin of the British Museum (Natural History). Zoology Series, 49, 1-162.

Phleger, F. B. (1960). Ecology and distribution of recent foraminifera. Baltimore, Maryland: Johns Hopkins University.
Phleger, F. B. (1964). Foraminiferal ecology and marine geology. Marine Geology, 1, 16-43.

Porrenga, D. H. (1967). Glauconite and chamosite as depth indicators in the marine environment. Marine Geology, 5, 495-501.

Radtke, G., Hofmann, K., \& Golubic, S. (1997). A bibliographic overview of micro- and macroscopic bioerosion. Courier Forschungsinstitut Senckenberg, 201, 307-340.

Seilacher, A. (1967). Bathymetry of trace fossils. Marine Geology, 5, 413-428.

Smith, A. B., Paterson, G. L. J., \& Lafay, B. (1995). Ophiuroid phylogeny and higher taxonomy: morphological, molecular and palaeontological perspectives. Zoological Journal of the Linnean Society, 114, 213-243.

Stöhr, S. (2011). New records and new species of Ophiuroidea (Echinodermata) from Lifou, Loyalty Islands, New Caledonia. Zootaxa, 3089, 1-50.

Stöhr, S., O’Hara, T.D. \& Thuy, B. (2012). Global diversity of brittle stars (Echinodermata: Ophiuroidea). PLoS One, 7(3), 1-14, e31940.

Stöhr, S. \& O’Hara, T.D. (2007). World Ophiuroidea database. http://www.marinespecies.org/ophiuroidea. Consulted 01 Feb 2012.

Thuy, B., Ishida, Y., Doi, E. \& Kroh, A. (2012). New ophiacanthid brittle stars (Echinodermata: Ophiuroidea) from the Upper Triassic of Japan: first insights into the origin and evolution of an extant deep-sea group. Journal of Systematic Palaeontology (in press).

Thuy, B., Gale, A. S., \& Reich, M. (2011). A new echinoderm Lagerstätte from the Pliensbachian (Early Jurassic) of the French Ardennes. Swiss Journal of Palaeontology, 130, 173-185.

Thuy, B., \& Stöhr, S. (2011). Lateral arm plate morphology in brittle stars (Echinodermata: Ophiuroidea): new perspectives for ophiuroid micropalaeontology and classification. Zootaxa, 3013, $1-47$.

Tyler, P. A. (1980). Deep-sea ophiuroids. Oceanography and Marine Biology Annual Review, 18, 125-153.

Verrill, A. E. (1899). Report on the Ophiuroidea collected by the Bahama expedition in 1893. Bulletin from the Laboratories of Natural History of the State University of Iowa, 5, 1-86.

Villier, L., Charbonnier, S., \& Riou, B. (2009). Sea stars from Middle Jurassic Lagerstätte of La Voulte-sur-Rhône (Ardèche, France). Journal of Paleontology, 83, 389-398.

Wetzel, A., Weissert, H. Schaub, M., and Voegelin, A.R. (2013). Seawater circulation on an oolite-dominated carbonate system in an epeiric sea (Middle Jurassic, Switzerland). Sedimentology, 60 (special issue) (in press). 